\title{
THE SENSITIVITY OF REGIONAL INCOME VARIATION TO CYCLICAL ECONOMIC FLUCTUATIONS
}

\author{
Orley M. Amos, Jr.*
}

This study investigates the relationship between regional income variation and cyclical economic fluctuations. This study asks the question: Is regional income variation directly or indirectly related to short run fluctuations in the economy? There are justifiable reasons for both direct and indirect relationships. If the economy experiences a "spurt" of growth, this could benefit the most developed areas greater, leading to greater variation between regions. On the other hand, if the lesser developed areas within the country receive the benefits of the short run growth, this would tend to reduce variation. This study seeks to identify which relationship, if any, exists between regional income variation and cyclical economic fluctuations.

Regional variation of per capita income is at the heart of many areas of investigation. The topic of regional dualism in the process of economic development has been discussed and analyzed by Chenery (1962), Kaldor (1970), Dixon and Thirlwall (1975), Guccione and Allen (1977), Kuznets (1955, 1963, 1973), and Williamson (1965). Regional income variation, on the other hand, is also a central theme of urban growth center literation by Perroux (1955), Lasuén (1969), Martin (1978, 1979a, 1979b), Martin and Graham (1980), Lewis and Prescott (1972), and Hansen (1967).

The impact of the U.S. economy's cyclical performance on regions within the U.S. has been investigated by Friedenberg and Bretzfelder (1980), and Bretzfelder (1973). Given that: (i) industries are differentially affected by the aggregate economy, and (ii) industries are often spatially concentrated, one would expect regions to be differentially affected by economic fluctuations. However, the relationship between the variation of per capital income between regions in the U.S. and cyclical economic fluctuations has not been studied.

*Oklahoma State University, Stillwater.
In the past five decades the U.S. has experienced a trend of reduced regional income variation. Figure 1, which presents the variation of state per capita income ${ }^{1}$ from the U.S. average, decreases from 0.41 in 1932 to 0.10 in 1979 . However, this decreasing trend is not without its fluctuations. While the long run development of the U.S. from 1929 to 1979 has been a major factor in reducing regional income variation, the question posed by this study is whether short run fluctuations in the economy contribute to the fluctuations of regional income variation depicted in Figure 1.

\section{Expected Results}

Three possible relationships between regional per capital income variation and cyclical fluctuations in the national economy can be demonstrated by Figure 2. In Figure 2(a), the growth of per capita output is depicted. The line A represents the actual short-run fluctuations in per capita output, and the line B represents the long-run growth trend. In the lower diagram (Figure 2(b)) the variation of income between regions, also over a period of time, is presented. Figure 2(b) depicts a simplified version of Figure 1. Figure 2(b) contains a long-run trend line for the variation of regional income (line I). If regional income variation is unaffected by short-run economic fluctuations, then curve I in Figure 2(b) would be associated with the actual short-run fluctuations depicted in Figure 2(a). This would imply that, given the historical trend of reduced regional income inequality in the U.S. due to increased development, minor fluctuations in the economy are not felt (from a development perspective) in the short-run. That is, regional income inequality is affected by long-run trends, such as changes in the stock of capita, public infrastructure, etc., but not by short-run changes in income, employment, etc.

The second possible result is a significant 


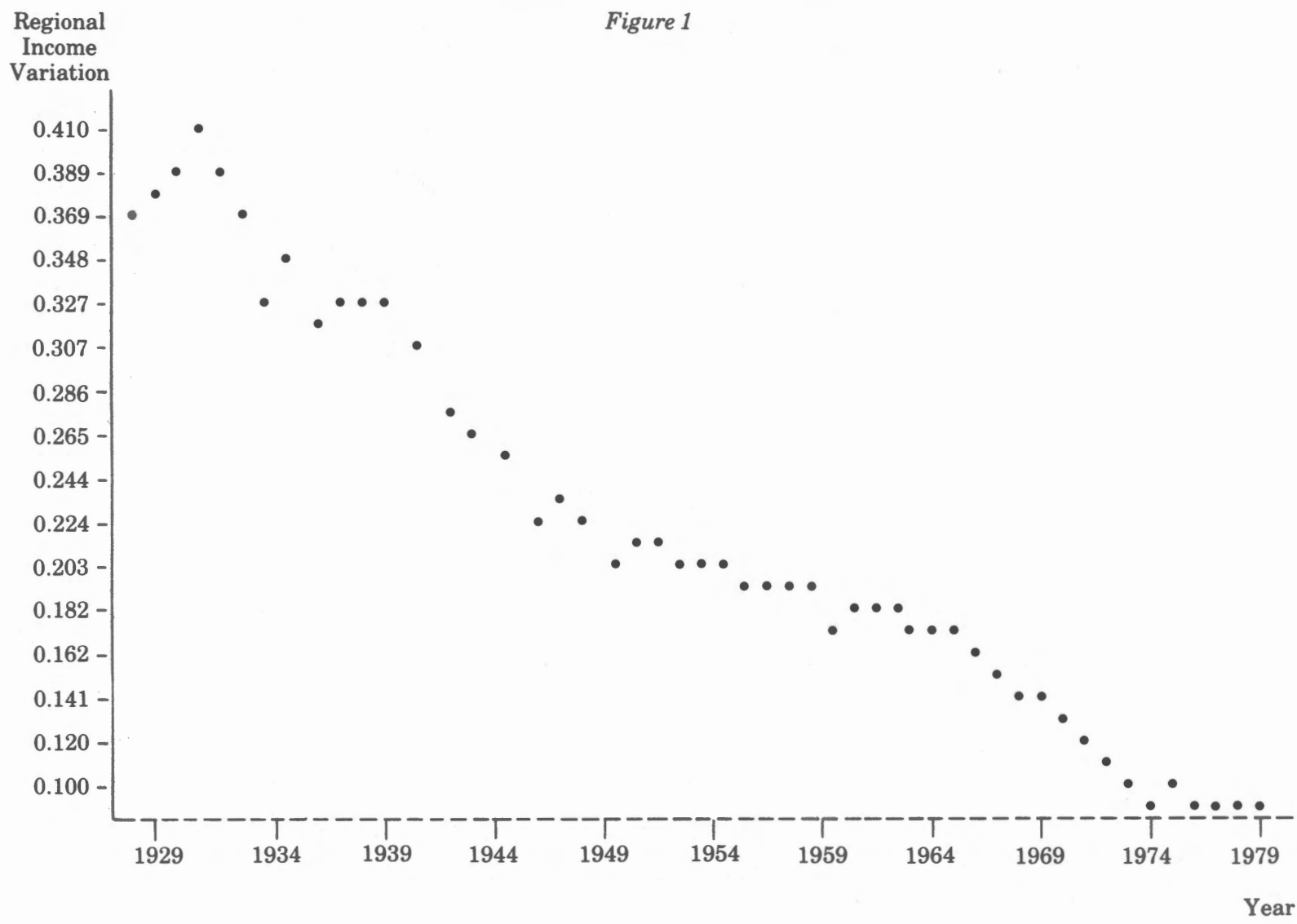

positive relationship between the cyclical performance of the economy and regional income variation as demonstrated by curve II in Figure 2(b). This result would imply that as the economy expands, regional income variation also expands, and would be consistent with a "take off" stage of development, (i.e. curve A in Figure 2(a) and curve II in Figure 2(b) rise and fall together). If a positive relationship is identified, then even in a developed economy and nation with relatively low levels of regional income variation, there are forces being exerted to increase regional income variation. Thus, two forces affecting regional income variation are discernable if a positive relationship is identified. One leading to increased variation due to economic expansion, the second leading to reduced variation as the expansion is disseminated throughout the nation in the normal course of development. Curve II in Figure 2(b)

Figure 2
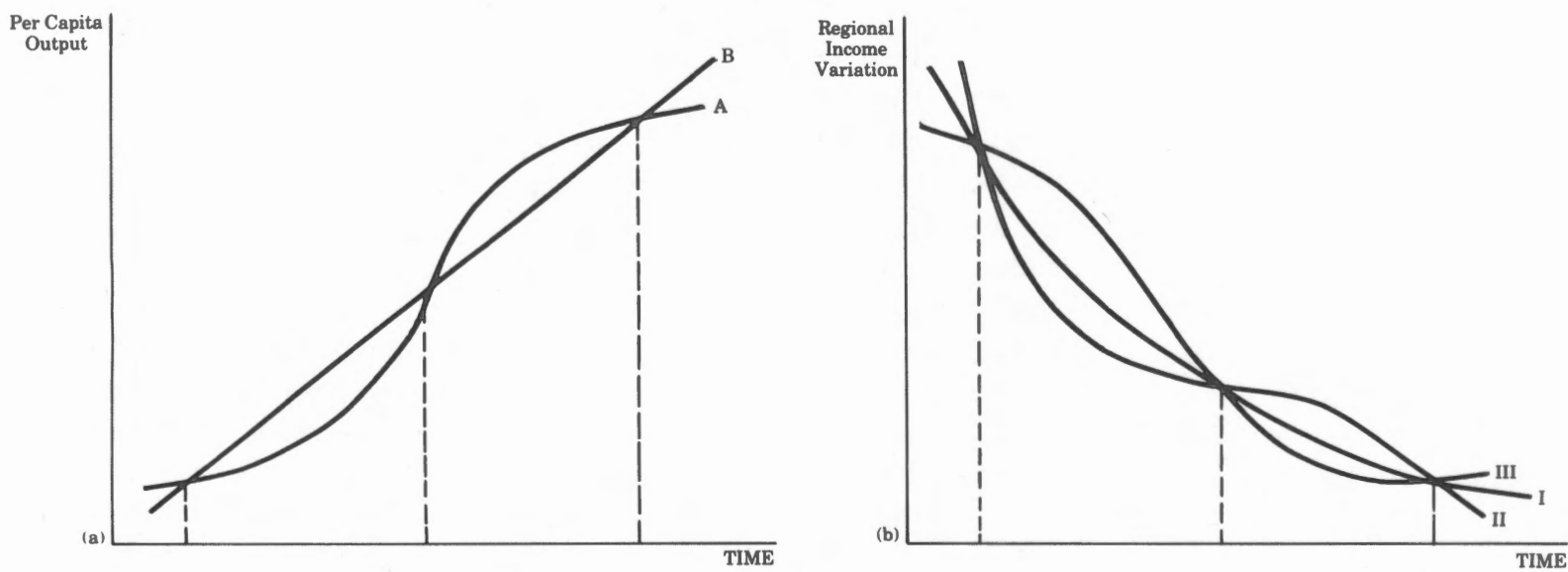
would be consistent with the "backwash" effect commonly referred to in development literature. As the economy "spurts" ahead this hypothesis implies the tendency for greater concentration. However, "spread" effects would then lead to the continued reduction in concentration, as indicated by Figure 1 .

The third possibility is a significant negative relationship between regional income variation and the cyclical performance of the U.S. economy as demonstrated by curve III in Figure 2(b). This result indicates that an expanding economy leads to reduced income variation, or that a "spurt" of development leads to a further reduction in variation, (i.e. curves III and A move in opposite directions). This third possibility implies a stronger relationship between regional income variation and development than any previous research in this area. It indicates that any growth in the economy leads to reduced income variation (or a recession leads to increased variation) without a short-run/ long-run distinction. This result provides no support for the traditional view of development, in which a growing economy initially experiences increasing income variation, then decreasing income variation.

\section{Methodology and Hypotheses}

To analyze the cyclical sensitivity of regional income variation, three analyses were undertaken. The first was based upon annual observations of the variation in per capita income between states in the U.S., from 1929-1979. Regression analysis is used to estimate the following equation:

$$
\mathrm{Vw}=\alpha+\beta_{1} \mathrm{D}+\beta_{3} \text { USGR }
$$

where:

$$
\begin{aligned}
\mathrm{Vw}= & \text { a measure of variation in state } \\
& \text { per capita income in the U.S., }
\end{aligned}
$$

In the first analysis $\beta_{3}$ was the coefficient of interest. If $\beta_{3}$ was not significant it would be consistent with line I in Figure 2(b) supporting the first hypothesis discussed in the previous section. On the other hand, $\beta_{3}>0$ would be consistent with line II in Figure 2(b), and $\beta_{3}<0$ would be consistent with line III in Figure 2(b).
The second analysis also employed BEA data, but the data were used to estimate Vw measures for multi-state regions instead of for the U.S. The analysis was based upon observations for the years 1929, 1940 and 1948 to 1979 for each of eight regions defined by the BEA. ${ }^{3}$ Equation 1 was estimated for each region, with the interpretation of $\beta_{3}$ similar to that in the first analysis, but with one exception. The second analysis tested for the sensitivity of multistate regions to national cyclical fluctuations. If $\beta_{3} \neq 0$ in the first analysis, the second analysis will indicate whether states generally are affected the same as larger regions, or whether they act independent of the regions.

The third analysis utilizes quarterly BEA data to estimate equation (1). This analysis will indicate whether there is a relative short term (less than one year) relationship between economic fluctuations and regional income variation.

\section{Cyclical Sensitivity of State Per Capita Income Variation in the U.S.: Annual Data}

This section presents the first analysis of the cyclical sensitivity of regional income variation using annual observations for the U.S. from 1929 to 1979 . Table 1 presents estimated results for equation (1) using three proxies for development: YEAR, Real Per Capita GNP (PCOUT), and Real Per Capita Personal Income (PCINC). All three equations in Table 1 were initially estimated using Ordinary Least Squares. However, serial correlation was evident, thus Table 1 presents regression equations corrected for serial correlation using the Cochrane-Orcutt method.

As anticipated all three equations indicated a negative relation between state income variation and development as D was negative and significant for each. However, an important difference between the three equations in Table 1 concerns the growth rate variable (USGR). For equation (2) the variable was negative and significant. For the remaining two equations USGR was not significant, being positive in equation (3) and negative in equation (4).

Taken alone equation (2) indicates support for a negative relation between the cyclical performance of the economy and state income variation. This implies that as the economy expands state income variation decreases. Thus, the cyclical growth of the economy, at least since 1929 , has apparently contributed to 
The Sensitivity of Regional Income Variation

TABLE 1

Regression Estimates of Equation 1: Annual Data

\begin{tabular}{|c|c|c|c|c|c|c|c|}
\hline $\begin{array}{c}\text { Develop- } \\
\text { ment } \\
\text { Proxy }\end{array}$ & $\begin{array}{c}\text { Equation } \\
\text { No. }\end{array}$ & Constant & D & $\mathrm{D}^{2}$ & USGR & $\mathrm{R}^{2}$ & $\begin{array}{l}\text { Durbin } \\
\text { Watson }\end{array}$ \\
\hline YEAR & (2) & $\begin{array}{c}.681 \\
(8.442)^{* * *}\end{array}$ & $\begin{array}{l}-.01180 \\
(-3.725)^{* * *}\end{array}$ & $\begin{array}{l}.00006 \\
(1.903)^{*}\end{array}$ & $\begin{array}{l}-.00052 \\
(-2.022)^{* *}\end{array}$ & $\begin{array}{r}.885 \\
(115.252)\end{array}$ & 1.5812 \\
\hline $\begin{array}{l}\text { PCOUT } \\
(\$ 000)\end{array}$ & (3) & $\begin{array}{c}.438 \\
(5.794)^{* * *}\end{array}$ & $\begin{array}{l}-.00700 \\
(-2.889)^{* * *}\end{array}$ & $\begin{array}{l}.00453 \\
(1.554)\end{array}$ & $\begin{array}{r}.00008 \\
(.290)\end{array}$ & $\begin{array}{c}.475 \\
(13.560)\end{array}$ & 1.6534 \\
\hline $\begin{array}{l}\text { PCINC } \\
(\$ 000)\end{array}$ & (4) & $\begin{array}{c}.472 \\
(6.720)^{* * *}\end{array}$ & $\begin{array}{l}-.10779 \\
(-2.651)^{* *}\end{array}$ & $\begin{array}{l}.00805 \\
(1.135)\end{array}$ & $\begin{array}{l}-.00002 \\
(-.0630)\end{array}$ & $\begin{array}{c}.565 \\
(19.466)\end{array}$ & 1.7283 \\
\hline
\end{tabular}

*Statistically significant at the 0.10 percent level

**Statistically significant at the 0.05 percent level

***Statistically significant at the 0.01 percent level

greater per capita income homogeniety between U.S. states. In times of growth the lesser developed states benefit more than the more developed states, thus reducing income variation. However, in times of recession, and negative growth, the lesser developed states are more adversely affected than the more developed states. This is consistent with line III in Figure 2(b).

Equations (3) and (4), which used real per capita output and income as development proxies, do not support the conclusions reached from analysis of equation (3). However, this apparent contradiction of the results in Table 1 , can provide a greater understanding of the relationship between cyclical fluctuations, development and state income variation. The objective of this paper was to distinguish the long-run relationship between development and state income variation from a short-run cyclical relationship. It was for this reason that YEAR was chosen as the development proxy. It was assumed that the long run trend in devel- opment has been relatively smooth and continual in the U.S. from 1929 to 1979. As such it was assumed that each subsequent year represents a greater level of development for the U.S. than previous years. Many aspects leading to increased development have a time span greater than a year (such as transportation systems, and other public infrastructure). Therefore a simple YEAR variable should more accurately proxy development than per capita output or income, which are affected by shortrun fluctuations in the economy in addition to long-run development trends.

Therefore it is not surprising that USGR was not significant in equations (3) and (4) which employed output and income as development proxies. Cyclical fluctuations in equations (3) and (4) were already contained in the output and income variables, making USGR a redundant variable.

The redundancy of USGR in equations (3) and (4) can be illustrated by analysis of Table 2 . In equations (7) and (8), PCOUT and PCINC

TABLE 2

Regressions of YEAR, YEAR², USGR, PCOUT and PCINC

\begin{tabular}{|c|c|c|c|c|c|c|c|c|}
\hline $\begin{array}{l}\text { Eq } \\
\text { No. }\end{array}$ & Const. & Year & Year $^{2}$ & PCOUT & PCINC & USGR & $\mathbf{R}^{2}$ & $\begin{array}{l}\text { Durbin } \\
\text { Watson }\end{array}$ \\
\hline (5) & $\begin{array}{c}.722 \\
(14.391)^{* * *}\end{array}$ & $\begin{array}{c}-.0134 \\
(-6.576)^{* * *}\end{array}$ & $\begin{array}{l}.000010 \\
(4.735)^{* * * *}\end{array}$ & $\begin{array}{l}-.03260 \\
(-4.735)^{* * *}\end{array}$ & - & - & $\begin{array}{c}.945 \\
(258.337)^{* *}\end{array}$ & 1.7446 \\
\hline (6) & $\begin{array}{c}.868 \\
(16.176)^{* * *}\end{array}$ & $\begin{array}{l}-.0162 \\
(-8.680)^{* * *}\end{array}$ & $\begin{array}{l}.00013 \\
(6.544)^{* * * *}\end{array}$ & - & $\begin{array}{l}-.06829 \\
(-5.243)^{* * *}\end{array}$ & - & $\begin{array}{c}.955 \\
(258.37)^{* *}\end{array}$ & 1.8283 \\
\hline (7) & $\begin{array}{c}.771 \\
(14.045)^{* * *}\end{array}$ & $\begin{aligned}- & .0134 \\
& (6.461)^{* * *}\end{aligned}$ & $\begin{array}{l}.000010 \\
(4.724)^{* * *}\end{array}$ & $\begin{array}{l}-.03190 \\
(-4.140)^{* * *}\end{array}$ & - & $\begin{array}{r}-.000050 \\
(-.188)\end{array}$ & $\begin{array}{c}.945 \\
(188.479)^{* *}\end{array}$ & 1.7542 \\
\hline$(8)$ & $\begin{array}{c}.864 \\
(15.321)^{* * *}\end{array}$ & $\begin{array}{c}-.0161 \\
(-8.311)^{* * *}\end{array}$ & $\begin{array}{l}.00013 \\
(6.094)^{* * *}\end{array}$ & - & $\begin{array}{l}-.06686 \\
(-4.677)^{* * *}\end{array}$ & $\begin{array}{l}-.00006 \\
(-.227)\end{array}$ & $\begin{array}{c}.955 \\
(230.963)^{* *}\end{array}$ & 1.8387 \\
\hline
\end{tabular}

\footnotetext{
*Statistically significant at the 0.10 percent level

$* *$ Statistically significant at the 0.05 percent level

***Statistically significant at the 0.01 percent level
} 
TABLE 3

Trend Regression Equations

\begin{tabular}{ccccccc}
\hline $\begin{array}{c}\text { Eq } \\
\text { No. }\end{array}$ & $\begin{array}{c}\text { Dependent } \\
\text { Variable }\end{array}$ & Const. & Year & Year & $\begin{array}{c}\mathrm{R}^{2} \\
\text { F-Value }\end{array}$ & $\begin{array}{c}\text { Durbin } \\
\text { Watson }\end{array}$ \\
\hline \multirow{2}{*}{$(9)$} & $\mathrm{Vw}$ & .684 & -.01199 & .00006 & .882 & 1.5280 \\
& & $(8.528)^{* * *}$ & $(-3.809)^{* * *}$ & $(2.036)^{* *}$ & $(179.395)$ & \\
$(10)$ & PCOUT & -.389 & .08316 & - & .570 & 1.0717 \\
& & $(-.698)$ & $(8.519)^{* * *}$ & & $(65.016)$ & \\
$(11)$ & PCINC & .0371 & .05308 & - & .435 & 1.2461 \\
& & $(.0743)$ & $(6.295)^{* * *}$ & & $(37.7646)$ & \\
\hline
\end{tabular}

*Statistically significant at the 0.10 percent level

**Statistically significant at the 0.05 percent level

***Statistically significant at the 0.01 percent level

were included in equation (2), respectively. In both cases the USGR variable was not statistically significant, but the newly included variable (PCOUT or PCINC) was highly significant, with the correct sign. Comparison of equations (7) and (8) with (5) and (6) indicates the redundancy of the USGR variables when PCOUT and PCINC were included. The three variables appear to be conveying the same information about the cyclical performance of the economy.

Equations (2) through (8), and Tables 1 and 2, offer strong support for the negative cyclical impact of the U.S. economy on state income variation. The results indicate that as the economy expands state income variation is reduced. Further support is possible by attempting to distinguish between a "trend" effect of development on state income variation, and a "cyclical" effect.

This analysis is accomplished in the following manner. First, "trend" regression equations were estimated using Vw, PCOUT and PCINC as dependent variables, as presented in Table 3. Each variable was regressed on YEAR variable (YEAR and YEAR ${ }^{2}$ for Vw). Secondly, fitted values of the dependent variables in Table 3 were estimated and subsequently error terms giving the deviation from actual and fitted values were estimated. Finally, error terms for $\mathrm{Vw}$ (equation 9) were regressed on error terms from equations (10) and (11). In this manner, the relationship depicted in Figure 2 can be identified. If cyclical fluctuations, as depicted by Figure 2(a), are associated with curve III in Figure 2(b), then the coefficients for the error terms regression should be negative. The converse is true if curve II is appropriate.

Table 4 presents the error terms regression analysis. In both equations (12) and (13) a negative and significant coefficient is evident. While the $R^{2} \mathrm{~S}$ were very low for both equations, Table 4 was consistent with the evidence presented in Tables 1 and 2 . At the national level the results presented in this section indicate an expanding economy leads to a lessening of state income variation across the entire U.S. In the following section this cyclical affect on regional income variation for multi-state regions of the U.S. is investigated.

\section{Cyclical Sensitivity of State Per Capita Income Variation in Multi-State Regions}

To extend the analysis from the previous section, attention is now focused on multi-state

TABLE 4

Regression of Error Terms from Trend Regression

\begin{tabular}{lccccc}
\hline $\begin{array}{c}\text { Equation } \\
\text { No. }\end{array}$ & Constant & PCOUT & PCINC & F-Value & $\begin{array}{c}\text { Durbin } \\
\text { Watson }\end{array}$ \\
\hline$(12)$ & -.026 & -.02846 & - & .261 & 1.7335 \\
$(13)$ & $-.021)$ & $(-4.164)^{*}$ & & $(17.345)$ & .233 \\
& & - & -.05132 & $(14.846)$ & 1.7395 \\
\hline
\end{tabular}

\footnotetext{
*Statistically significant at the 0.10 percent leve

**Statistically significant at the 0.05 percent level

***Statistically significant at the 0.01 percent level
} 
TABLE 5

Regressions of Regional Vw's on YEAR, YEAR ${ }^{2}$ and USGR

\begin{tabular}{|c|c|c|c|c|c|c|c|}
\hline Region & $\begin{array}{c}\text { Equation } \\
\text { No. }\end{array}$ & Constant & YEAR & YEAR $^{2}$ & USGR & $\begin{array}{c}\mathbf{R}^{2} \\
\text { (F-Value) }\end{array}$ & $\begin{array}{l}\text { Durbin } \\
\text { Watson }\end{array}$ \\
\hline $\begin{array}{l}\text { New } \\
\text { England }\end{array}$ & (14) & $\begin{array}{l}.1142 \\
(2.697)^{* *}\end{array}$ & $\begin{array}{l}.00172 \\
(1.152)\end{array}$ & $\begin{array}{l}-.00003 \\
(-1.915)^{*}\end{array}$ & $\begin{array}{r}.00026 \\
(.401)\end{array}$ & $\begin{array}{c}.649 \\
(18.449)^{* * *}\end{array}$ & 1.7594 \\
\hline Mideast & (15) & $\begin{array}{l}.3798 \\
(8.128)^{* * *}\end{array}$ & $\begin{array}{l}-.00729 \\
(-3.939)^{* * *}\end{array}$ & $\begin{array}{l}.00004 \\
(2.323)^{* *}\end{array}$ & $\begin{array}{c}-.000301 \\
(-.652)\end{array}$ & $\begin{array}{c}.824 \\
(46.940)^{* * *}\end{array}$ & 2.1216 \\
\hline $\begin{array}{l}\text { Great } \\
\text { Lakes }\end{array}$ & (16) & $\begin{array}{c}.2840 \\
(11.851)^{* * *}\end{array}$ & $\begin{array}{l}-.00595 \\
(-6.336)^{* * *}\end{array}$ & $\begin{array}{l}.00004 \\
(4.434)^{* * *}\end{array}$ & $\begin{array}{l}-.00041 \\
(-1.675)\end{array}$ & $\begin{array}{c}.900 \\
(90.377)^{* * *}\end{array}$ & 1.6425 \\
\hline Plains & (17) & $\begin{array}{l}.2519 \\
(5.057)^{* * *}\end{array}$ & $\begin{array}{l}-.00555 \\
(-3.266)^{* * *}\end{array}$ & $\begin{array}{l}.00003 \\
\quad(2.579)^{* *}\end{array}$ & $\begin{array}{r}.00003 \\
(.031)\end{array}$ & $\begin{array}{c}.565 \\
(12.978)^{* * *}\end{array}$ & 1.9772 \\
\hline $\begin{array}{l}\text { South } \\
\text { East }\end{array}$ & (18) & $\begin{array}{l}.3379 \\
(9.024)^{* * *}\end{array}$ & $\begin{array}{l}-.00541 \\
(-4.372)^{* * *}\end{array}$ & $\begin{array}{l}.00003 \\
(2.771)^{* * *}\end{array}$ & $\begin{array}{c}.00016 \\
(-.201)\end{array}$ & $\begin{array}{c}.860 \\
(61.592)^{* * *}\end{array}$ & 1.7441 \\
\hline $\begin{array}{l}\text { South } \\
\text { West }\end{array}$ & (19) & $\begin{array}{l}.1555 \\
(3.736)^{* * *}\end{array}$ & $\begin{array}{l}-.00358 \\
\quad(-2.411)^{* *}\end{array}$ & $\begin{array}{l}.00003 \\
(1.970)\end{array}$ & $\begin{array}{l}.00070 \\
(1.207)\end{array}$ & $\begin{array}{c}.466 \\
(8.714)^{* * *}\end{array}$ & 2.2462 \\
\hline $\begin{array}{l}\text { Rocky } \\
\text { Mountain }\end{array}$ & (20) & $\begin{array}{l}.1891 \\
(3.007)^{* * *}\end{array}$ & $\begin{array}{l}-.00476 \\
(-2.146)^{* *}\end{array}$ & $\begin{array}{l}.00005 \\
(2.439)^{* * *}\end{array}$ & $\begin{array}{l}.00148 \\
(1.5671)\end{array}$ & $\begin{array}{c}.338 \\
(5.112)^{* * *}\end{array}$ & 1.9763 \\
\hline $\begin{array}{l}\text { Far } \\
\text { West }\end{array}$ & (21) & $\begin{array}{l}.2851 \\
(5.912)^{* * *}\end{array}$ & $\begin{array}{l}-.00628 \\
(-3.542)^{* * *}\end{array}$ & $\begin{array}{l}.00004 \\
(2.473)^{* * *}\end{array}$ & $\begin{array}{r}.00030 \\
(.509)\end{array}$ & $\begin{array}{c}.720 \\
(25.691)^{* * *}\end{array}$ & 2.0676 \\
\hline
\end{tabular}

*Statistically significant at the 0.10 percent level

**Statistically significant at the 0.05 percent level

***Statistically significant at the 0.01 percent level

subregions of the U.S. Variation within eight regions delineated by the BEA was estimated, and regression analyses similar to the previous section were performed. For each region presented in Table 5 (New England, Mideast, Great Lakes, Plains, Southeast, Southwest, Rocky Mountain and Far West) the variation of state per capita income from the regional average was estimated for 1929,1940 and 1948 to 1979. For each region two regression equations were estimated. In Table 5 results of the equations regressing each regional $\mathrm{Vw}$ measure on independent variables YEAR, YEAR ${ }^{2}$ and USGR are presented. Year was used in this analysis as the sole proxy for development due to the lack of acceptable real state per capita output and income time series data. In addition, the results obtained in the previous section indicate YEAR was a more appropriate variable.

With the exception of equation (14) for the New England region, the results in Table 5 were relatively consistent. The other seven regions have YEAR and YEAR ${ }^{2}$ coefficients with the expected signs, negative and positive, respectively. Results which were consistent with equation (2) in Table 1.

The key analysis however, comes from analysis of the coefficient of USGR. In every equation in Table 5, the coefficient for the growth rate variable was not significant at the 0.05 level. In only the Great Lakes and Rocky Mountain equations was the coefficient significant at a level above 0.20 . This indicates a conclusion worth underscoring. The cyclical performance of the economy does not affect variation of per capita income within regions of the U.S. Taking into consideration the conclusion reached from the previous section: that the cyclical performance affects state per capita income variation with the entire U.S., an interesting, though not totally unexpected, picture can be presented. Cyclical fluctuations of the U.S. economy lead to changes in variation of state per capita income. However, the states do not act independently of each other. Based on the results in Table 5, the regions specified by the BEA appear to be affected nearly the same, with respect to cyclical fluctuation.

Therefore, it is not so much the variation of state per capita income, but the variation of major multi-state regions. For example, the New England region may be affected by a downturn in the economy, but the states within the region are all affected the same, thus variation of per capita income within the New England region is not affected. However, the New England region and the states in the New England region may be affected indifferently from other states in major regions. 
TABLE 6

Quarterly Regression Estimates of Equation 1

\begin{tabular}{ccccccc}
\hline $\begin{array}{c}\text { Equation } \\
\text { No. }\end{array}$ & Constant & YEAR & YEAR & USGR & $\begin{array}{c}\text { R2 } \\
\text { (F-Value) }\end{array}$ & $\begin{array}{c}\text { Durbin } \\
\text { Watson }\end{array}$ \\
\hline$(22)$ & .717 & -.01131 & .00005 & - & .934 & 2.1544 \\
& $(4.454)^{* * *}$ & $(-2.4641)^{* *}$ & $(1.388)$ & & $(539.978)^{* * *}$ & \\
$(23)$ & .712 & -.01134 & .00005 & -.00004 & .934 & 2.1580 \\
& $(4.399)^{* * *}$ & $(-2.436)^{* *}$ & $(1.374)$ & $(-.242)$ & $(351.920)^{* * *}$ & \\
\hline
\end{tabular}

*Statistically significant at the 0.10 percent level

**Statistically significant at the 0.05 percent level

***Statistically significant at the 0.01 percent level

\section{Cyclical Sensitivity of State Per Capita Income Variation in the U.S.: Quarterly Data}

To test for the short-run sensitivity of regional income variation to economic fluctuations, quarterly estimates of $\mathrm{Vw}$ were obtained, and equation (1) was estimated using YEAR as the proxy for development. Quarterly data for years 1960 to 1979 were used, giving 80 observations. Table 7 presents the results.

As expected, the coefficient for YEAR was negative and significant. However, the coefficient for $\mathrm{YEAR}^{2}$ was positive, as expected, but not significant. The coefficient for USGR was negative as expected but also not significant. This indicates short term economic fluctuations, of less than one year, do not have an impact on regional income variation. To test for a delayed relationship between economic fluctuations and regional income variation, USGR was lagged up to eight quarters. Although not presented here, the results were consistent with equation (23). In none of the equations was USGR statistically significant at the 0.05 percent level.

In that the analysis using annual data indicated a significant relationship between economic fluctuations and regional income variation, the results in Table 6 are particularly interesting. Annual and quarterly results taken together indicated regional income variation was sensitive to relatively sustain fluctuations in the economy (one year), but not to shorter fluctuations (less than one year). This indicates there was not an instantaneous reaction by U.S. regions to economic fluctuations. And any changes in regional income variation are the result of sustained fluctuations.

\section{Conclusion and Summary}

This paper has presented evidence concerning the relationship between cyclical economic fluctuations and regional income variation. The results indicate that the variation of per capita income between states at the national level is sensitive to sustained economic fluctuations of a year. However, shorter fluctuations of less than one year do not effect regional income variation.

While there has been ample evidence to suggest a long-run development trend for regional income variation (see Figure 1), these results indicate regional income variation is affected by short-run economic fluctuations as well. However, the short-run fluctuations must be greater than a year. This indicates that, while the development process (leading to improved transportation systems, and other social infrastruction) leads to reduced income variation, so will short-run fluctuations of the economy. However, the short-run fluctuations must be sustained for a long enough period to allow the regional economies time to adjust.

The results in this study also indicate that the variation of state per capita income within multi-state region is not sensitive to national economic fluctuations. This indicates that the multi-state regions identified by the BEA are relatively homogeneous in the reaction to national economic fluctuations. It also indicates that it is the variation between multi-state regions, and not so much between states, that is affected by national economic fluctuations.

\section{FOOTNOTES}

'Data used for Figure 1 were derived from Williamson (1965) for the years 1929 to 1947 and estimated for this study using equation (2).

2The measure of per capita income variation was the same as used by Williamson (1965), and was defined as:

$$
V w=\frac{\sqrt{\sum_{i=1}^{n}\left(Y_{i}-\bar{Y}\right)^{2} \frac{f_{i}}{N}}}{\bar{Y}}
$$

where: $Y_{i} \quad=$ per capita income in state $i$,

$\overline{\mathbf{Y}}=$ U.S. per capita income,

$\mathbf{f}_{\mathrm{i}} \quad$ population in state $\mathrm{i}$,

$\mathrm{N}=$ U.S. population, and

n $\quad$ number of states. 
Data used to estimate equation (1) were derived from the National income and Product Accounts for the right hand side variables. Two sources were used to obtain the 51 year time series estimate for Vw. First, in Willamson's (1965) study Vw estimates were obtained from 1929 to 1947 . Second, U.S. Department of Commerce, Bureau of Economics Analysis (BEA) data were used to estimate $V w$ from 1948 to 1979 . In that $\mathrm{Vw}$ was estimated from two sources, equation (1) was initially estimated with a dummy variable (equal to 1 for observations from 1929-1947 and 0 otherwise). However, the dummy variable was not statistically significant and was thus dropped from the analysis.

${ }^{3}$ The regions, and states contained in each are: New England-Connecticut, Maine, Massachusetts, New Hampshire, Rhode Island, and Vermont; Mideast-Delaware, Maryland, New Jersey, New York, and Pennsylvania; Great Lakes-Illinois, Indiana, Michigan, Ohio, and Wisconsin; Plains-Iowa, Kansas, Minnesota, Missouri, Nebraska, North Dakota, and South Dakota; SoutheastAlabama, Arkansas, Florida, Georgia, Kentucky, Louisiana, Mississippi, North Carolina, South Carolina, Tennessee, Virginia, and West Virginia; Southwest-Arizona, New Mexico, Oklahoma, and Texas; Rocky Mountain-Colorado, Idaho, Montana, Utah, and Wyoming; and Far West-California, Nevada, Oregon, and Washington.

\section{REFERENCES}

Bretzfelder, R. B., "Sensitivity of State and Regional Income to National Business Cycles," Survey of Current Business, (April 1973), 22-27.

Dixon, R. and A. P. Thirlwall, "A Model of Regional Growth-rate Differences on Kaldorian Lines," Oxford Economic Papers, (1975), 201-214.

Friedenberg, H. and R. Bretzfelder, "Sensitivity of Regional and State Nonfarm Wages and Salaries to National Business Cycles, 1948-1979, "Survey of Current Business, (May 1980), 15-27.
Guccione, A. and W. J. Allen, "Growth Rate Stability in the Kaldorian Regional Model," Scottish Journal of Political Economy, 24 (1977), 175-176.

Hansen, N.M., "Development Pole Theory in a Regional Context," Kyklos, 20 (1967), 709-725.

Kaldor, N., "The Case for Regional Policies," Scottish Journal of Political Economy, 17 (1970), 337-347.

Kuznets, S., "Economic Growth and Income Inequality," American Economic Review, 45 (1955), 1-28.

Kuznets, S., "Distribution of Income by Size," Economic Development and Cultural Change, 11 (1963), 1-80.

Kuznets, S., "Modern Economic Growth: Findings and Reflections," American Economic Review, 63 (1973), 247-258.

Lasuén, J. R., “On Growth Poles," Urban Studies, (1969), 137-161.

Lewis, W. C. and Prescott, J., "Urban-Regional Development and Growth Centers: An Econometric Approach," Journal of Regional Science, 12 (1972), 57-70.

Martin, R. C., "An Empirical Inquiry into the Effectiveness of the Growth Center Approach to Regional Economic Development," The Review of Regional Studies, 8 (1978), 1-19.

Martin, R. C., "Legislation Versus Administration: An Empirical Note on Federal Regional Development Programs," Growth and Change, 10 (1979a), 46-49.

Martin, R. C., "Federal Regional Development Programs and U.S. Problem Areas," Journal of Regional Science, 19 (1979b), 157-170.

Martin, R. C. and Graham, R. E., Jr., "The Impact of Economic Development Administration Programs: Some Empirical Evidence," Review of Economics and Statistics, 62 (1980), 52-62.

Perroux, F., "Note on the Concept of Growth Poles (1955)," in D. McKee, R. Dean and W. Leahy (eds.) Regional Economics: Theory and Practice (New York: The Free Press, 1970), 93-104.

Williamson, Jeffrey G., "Regional Inequality and the Process of National Development: A Description of the Patterns," Economics Development and Cultural Change, 13 (1965), 1-45. 